\title{
The effects of Psidium guajava leaf extract on the production of cellulases and glucose oxidases by Aspergillus niger
}

\author{
Isheanesu Dzambi ${ }^{1}$ and Rumbidzai Mangoyi ${ }^{1, *}$ \\ Department of Biochemistry, University of Zimbabwe, Mt. Pleasant, Harare, Zimbabwe.
}

Publication history: Received on 16 November 2020; revised on 23 November 2020; accepted on 25 November 2020

Article DOI: https://doi.org/10.30574/gscarr.2020.5.2.0109

\begin{abstract}
Aspergillus niger, is a filamentous fungus and producer of industrial enzymes such as glucose oxidases and cellulases. These enzymes are naturally produced by the fungus in order to digest and absorb nutrients from its environment. However, the enzyme quantities that are naturally produced are low. Thus, the aim of this study was to determine the effects of Psidum guajava leaf extract on the production of cellulases and glucose oxidases from Aspergillus niger. The leaves of Psidium guajava were extracted using absolute methanol. Aspergillus niger was then grown in the presence and absence of the extract in order to investigate the effects of extract on enzyme production by the fungus. The enzymes secreted into the broth medium were isolated by centrifugation. The supernatant which contained the secreted enzymes was used for the determination of enzyme activity. Enzyme activity was determined using the specific substrate for the specific enzyme, such as $2 \%$ cellulose for cellulase and standard glucose solution for glucose oxidase. The results showed that the Psidium guajava leaf extract had an effect on production and activity of cellulases and glucose oxidases. From this study, it was noted that the Psidium guajava leaf extract may be used to induce the production of enzymes by Aspergillus niger and these enzymes may be of industrial use.
\end{abstract}

Keywords: Aspergillus niger, Psidium guajava, cellulase, glucose oxidase.

\section{Introduction}

Aspergillus niger is a filamentous fungus which is mainly found in common mesophilic environments such as soil, enclosed air environments, decaying starchy fruits and vegetables or plants. It can grow on large variety of substances even within environment with very little nutrients, hence, is the most abundant species in nature [1]. Aspergillus niger releases enzymes which help in food absorption, a neccessity for growth and reproduction of this fungus [2]. The produced enzymes have been reported to be of great importance in the industrial sector. Aspergillus niger being a thermophile fungi produces enzymes which are thermostable [1]. The applications of these enzymes have been well established in different industries such as textile, medicines, detergent and animal feeds [3]. Extracellular enzymes produced by Aspergillus niger include proteases, lipases, amylases, glucose oxidases, xylanases and cellulases.

Cellulases were studied and seen to be mainly produced through microbial species with Aspergillus niger generating excessive quantities of commercially used cellulases. This is because of the thermostability of cellulase produced by the fungus $[4 ; 5 ; 6]$. Cellulases are hydrolytic enzymes that act on cellulose. They hydrolyse $\beta-1,4$ glycosidic linkages in cellulose chains. Cellulose is a polysaccharide of many glucose residues that are joined together by $\beta 1,4$ linkages.

Glucose oxidase is a flavoprotein that catalyses the oxidation of $\beta$-D glucose [7]. It is a homodimeric enzyme which has two identical polypeptide chain subunits of about $80 \mathrm{kDa}$ each. The two subunits are joined covalently by disulphide bonds. The enzyme was first discovered in 1928 by Muller in Aspergillus niger extracts. Glucose oxidase from Aspergillus

\footnotetext{
* Corresponding author: Rumbidzai Mangoyi

Department of Biochemistry, University of Zimbabwe, Mt. Pleasant, Harare, Zimbabwe.
}

Copyright (C) 2020 Author(s) retain the copyright of this article. This article is published under the terms of the Creative Commons Attribution Liscense 4.0. 
niger has $20 \%$ amino sugar, 16-19\% carbohydrates of which $80 \%$ is N/O glycosidically linked mannose molecules [8] and does not require activators. It oxidises $\beta$-D glucose into D gluconolactone and hydrogen peroxide [9]. Fungal glucose oxidase is widely used in food and pharmaceutical industries.

Thus, this study is focusing on determining the effect of Psidium guajava plant extract on the production of cellulase and glucose oxidase from Aspergillus niger. Psidium guajava L. also known as (Guava), belongs to the family Myrtaceae which is widely distributed in tropical and warm temperature regions of the world [10]. Psidium guajava is rich in tannins, triterpens, flavonoids, essential oil, saponins, lactins, vitamins, fiber, fatty acids, alanine, oxalic acid, 119yanidin acid, quercetin, glutamic acid, D-glactose and 119yaniding [11].

Inducing the production of enzymes using Psidium guajava, and isolating them for industrial use would reduce the importation costs, pollution and global warming. These environmental benefits of Cleaner Production can also be translated into market opportunities for 'greener' products. Guava is being used as an inducer of enzyme production because it has been previously reported to have antifungal activity and it is readily available [12]. As an antifungal agent, guava extracts can induce the production of enzymes by attacking Aspergillus niger, and as a defense mechanism, A. niger produces enzymes.

\section{Material and methods}

\subsection{Extraction of Psidium guajava}

Guava leaves were dried over the sun for three days and then were processed into powder using mortar and pestle. The powdered leaves were extracted using absolute methanol. The extraction powder to solvent ratio was 1:4. The extracted sample was filtered using a whatman paper and the filtrate was dried over the fan. The dried extract was stored at room temperature until use.

\subsection{Resuscitation of Aspergillus niger}

The Aspergillus cells were resuscitated on potato dextrose agar for seven days in an incubator at $37{ }^{\circ} \mathrm{C}$ to allow for complete sporulation.

\subsection{Crude enzyme extraction}

Mature Aspergillus cells were inoculated into two separate flasks containing nutrient broth and were allowed to grow for seven days in the presence of Psidium guajava methanol leaf extract at half the minimum inhibitory concentration reported [12], at $150 \mathrm{rpm}$ and $37^{\circ} \mathrm{C}$. Using the assumption that Aspergillus niger released enzymes into the solution as a way of defence, the solution was centrifuged and the supernatant was collected as crude enzyme and stored at $4{ }^{\circ} \mathrm{C}$ for enzyme assays.

\subsection{Enzyme activity determination}

\subsubsection{Cellulases}

The Activity of cellulase was determined spectrophotometrically at $540 \mathrm{~nm}$ by measuring the absorbance of glucose produced when the enzyme cellulase was incubated in the presence of cellulose. Glucose standard solution was prepared by adding $0.1 \mathrm{~g}$ in $100 \mathrm{ml}$ distilled water to make a concentration of $1 \mathrm{~g} / \mathrm{l}$. Different concentrations of glucose $(0.0,0.2,0.4,0.6,0.8$, and 1$)$ were prepared by mixing glucose standard solution, $2 \mathrm{ml}$ of Dinitrosalicylic acid reagent and distilled water. Dinitrosalicylic acid reagent was prepared by adding $2.18 \mathrm{~g}$ of 3.5 Dinitrosalicylic acid to $80 \mathrm{ml}$ of $0.5 \mathrm{M} \mathrm{NaOH}$. Dinitrosalicylic acid was dissolved by stirring and heating at $70{ }^{\circ} \mathrm{C}$. A mass of $30 \mathrm{~g}$ of sodium potassium tartrate was added and mixed till it was completely dissolved. The standards solutions were then incubated at $50{ }^{\circ} \mathrm{C}$ in a water bath for 10 minutes. The tubes were cooled and then after that $7 \mathrm{ml}$ of distilled water was added. The absorbance was read at $540 \mathrm{~nm}$.

For the test samples, $2 \%$ cellulose was prepared by dissolving $2 \mathrm{~g}$ of cellulose powder in $100 \mathrm{ml}$ distilled water. A suspension was formed as cellulose is insoluble in water. $50 \mathrm{mM}$ sodium citrate buffer was prepared by adding 24.096 g sodium citrate dehydrate and $3.471 \mathrm{~g}$ of citric acid to $1000 \mathrm{ml}$ of distilled water and mixed till completely dissolved. $\mathrm{pH}$ was adjusted using $\mathrm{NaOH}$.

Sodium citrate buffer, enzyme extract produced in the absence of leaf extract, and $2 \%$ cellulose were added to the falcon tube and the solution was subjected to shaking at $50{ }^{\circ} \mathrm{C}$ and $150 \mathrm{rpm}$ for 10 minutes. The reaction was stopped by the addition of $0.5 \mathrm{ml}$ DNS. The tube was submerged in a boiling water bath for 5 minutes. The tube was cooled to room 
temperature and $6.5 \mathrm{ml}$ of distilled water was added. Absorbance was read at $540 \mathrm{~nm}$. Glucose concentration released upon hydrolysis of cellulose by cellulase was determined using the standard curve. The concentration was used to calculate the activity of the cellulase in mol/second (katals). Cellulase enzyme activity was calculated using the formulas: Activity $(\mathrm{katal})=$ moles of glucose liberated $/$ second $=$ [glucose $] \times[1 / 180 \mathrm{~g}] \times$ [8.5 ml/1000 ml] $\times$ [1/600 seconds]. 1 katal $=60000000 \mathrm{U}$ (enzyme unit).

The procedure was done in duplicate using enzyme extract (Supernatant of cells only, cells plus $1 \mathrm{mg}, 1.5 \mathrm{mg}$ and $2 \mathrm{mg}$ of the leaf extract of Psidium guajava).

\subsubsection{Glucose oxidases}

The enzyme activity was determined spectrophotometrically by reading absorbance when the enzyme glucose oxidase oxidizes glucose to D-gluconolactone and $\mathrm{H}_{2} \mathrm{O}_{2}$. Glucose standard solution was prepared by dissolving $100 \mathrm{mg}$ of glucose in $100 \mathrm{ml}$ of $0.1 \%$ benzoic acid. Different concentrations of glucose $(0.0,0.2,0.4,0.6,0.8$, and 1$)$ were prepared by mixing glucose standard solution, $5 \mathrm{ml}$ of glucose oxidase reagent and distilled water. Glucose oxidase reagent was prepared by adding $0.3 \mathrm{ml}$ of glucose oxidase in $80 \mathrm{ml}$ of $0.1 \mathrm{M}$ acetate buffer $\mathrm{pH} 5$ followed by the addition of $5 \mathrm{ml}$ of peroxidase solution and $1 \mathrm{ml}$ of $0.5 \%$ ortho-dianisidine hydrochloride. The volume was made up to $100 \mathrm{ml}$ with distilled water. The standard solutions were then incubated at $50^{\circ} \mathrm{C}$ in a water bath for 10 minutes.

For the test samples, Glucose oxidase (test solution) from the supernatant of cells grown in the absence of the extract, cells grown in the presence of $1 \mathrm{mg}$ extract, $1.5 \mathrm{mg}$ and $2 \mathrm{mg}$ of extract was used. Thus, to $1 \mathrm{ml}$ of glucose standard solution, $5 \mathrm{ml}$ of glucose oxidase (test solution) was added. The procedure was done in duplicate. The tubes (tests and standards) were mixed and incubated in a water bath at $37^{\circ} \mathrm{C}$ for 10 minutes. At the end of incubation $1 \mathrm{ml}$ of $0.5 \mathrm{M}$ sulphuric acid was added which stops the enzyme reaction, eliminates turbidity and stabilize the amber colour. Absorbance was read at $420 \mathrm{~nm}$. The absorbances of glucose standard samples obtained were used to prepare standard curve in order to determine the concentration of test samples. The concentration was used to calculate the activity of the glucose oxidase in mol/second (katals). Glucose oxidase enzyme activity was calculated using the formulas: Activity $(\mathrm{katal})=$ moles of glucose used $/$ second $=[$ glucose $] \times[1 / 180 \mathrm{~g}] \times[6 \mathrm{ml} / 1000 \mathrm{ml}] \times[1 / 600 \mathrm{~seconds}] .1 \mathrm{katal}=60000000 \mathrm{U}$ (enzyme unit)

\subsection{Statistical analysis}

Data analysis was done by Graph Pad Prism 5 to obtain the standard deviation of the enzyme activity.

\section{Results and discussion}

\subsection{Glucose oxidase activity determination}

The glucose oxidase assay was carried out to determine the concentration and activity of enzyme produced in the absence and presence of the Psidium guajava leaf extract. The results interpolated from the glucose standard curve show that the presence of the extract increased concentration of glucose oxidase enzyme produced by Aspergillus niger. The effect of increasing concentration of extract on the production of glucose oxidase by Aspergillus niger was also determined and results show an increase in activity as the concentration of the extract increased (Table 1). This increase could be due to the fact that the leaf extract is an inducer of the enzyme. When the concentration of an inducer is increased, more mRNA encoding the synthesis of enzymes on Aspergillus niger will be synthesized and expressed resulting in more production of the enzyme of interest [13]. Increasing enzyme concentration on constant substrate concentration (glucose), resulted in an increase in enzyme activity. There was more of the amount of the enzyme to catalyze glucose resulting in more glucose being converted to gluconic acid and hydrogen peroxide. The increased amount of hydrogen peroxide oxidized ortho-dianisidine resulting in a more intense brown colour being formed which was measured at $420 \mathrm{~nm}$.

\subsection{Cellulase activity determination}

The cellulase assay was measured by the production of glucose from the complete hydrolysis of cellulose. Therefore, the presence of cellulase in solution was measured against the glucose standard curve.

Dinitrosalicylic acid readings are strongly influenced by the reducing end ration of glucose, cellobiose and longer cellodextrins [14]. The DNS method was capable of detecting activity of cellulase obtained from Aspergillus niger using 
carboxymethyl cellulose as the substrate. The method was capable of detecting D-glucose liberated from CMC over time [15]

Increasing the amount of extract had an effect in increasing the amount of enzyme produced and available in solution. An increase of cellulase accessibility to cellulose results in faster hydrolysis rates [16; 17]. As the hydrolysis rates were increased, more glucose was liberated which reduced DNS reagent (yellow) to 3-amino-5-nitrosalicylic acid (orangereddish) which strongly absorbs at $540 \mathrm{~nm}$. Colour changes from yellow to orange-reddish brown were observed with an increase in hydrolysis rate. The more the glucose produced, the more intense the colour of the reduced dinitrosalicylic acid and the greater the absorbance. The reaction with cellulase obtained from the solution with $2 \mathrm{mg}$ extract had the most intense colour and greatest absorbance, hence increased activity as shown in table 1.

Table1. The effects of increasing extract concentration on glucose oxidase and cellulase activity.

\begin{tabular}{|l|l|l|l|l|}
\hline \multirow{2}{*}{ Source of enzyme } & \multicolumn{2}{|c|}{ Glucose oxidase } & \multicolumn{2}{c|}{ Cellulase } \\
\cline { 2 - 5 } & $\begin{array}{l}\text { Mols/second } \\
\text { katal) }\end{array}$ & $\mu$ mol/minute (U) & $\begin{array}{l}\text { Mols/second } \\
(\mathrm{katal})\end{array}$ & $\mu$ mols/minute (U) \\
\hline Cells only & $1.56 \times 10^{-8}$ & 0.936 & $4.01 \times 10^{-8}$ & 2.406 \\
\hline $\begin{array}{l}\text { Cells + 1 mg } \\
\text { extract }\end{array}$ & $2.12 \times 10^{-8}$ & 1.272 & $4.71 \times 10^{-8}$ & 2.826 \\
\hline $\begin{array}{l}\text { Cells + } 1.5 \mathrm{mg} \\
\text { extract }\end{array}$ & $2.53 \times 10^{-8}$ & 1.518 & $5.35 \times 10^{-8}$ & 3.210 \\
\hline $\begin{array}{l}\text { Cells + } 2 \mathrm{mg} \\
\text { extract }\end{array}$ & $2.79 \times 10^{-8}$ & 1.674 & & \\
\hline
\end{tabular}

\section{Conclusion}

Psidium guajava leaf extract induced the production of cellulases and glucose oxidases by Aspergillus niger. The fungus produced a strong defence system against the antifungal which led to the production of the enzymes of interest. The previously reported active compounds, limonene and oleanolic acids may have the ability to induce expression of genes responsible for the translation and release of enzymes.

\section{Compliance with ethical standards}

\section{Acknowledgments}

This study was sponsored by the Department of Biochemistry at the University of Zimbabwe, and the University of Zimbabwe Research Board (Harare, Zimbabwe) is also acknowledged.

\section{Disclosure of conflict of interest}

The authors report no conflicts of interest. The authors alone are responsible for the content and writing of the paper.

\section{References}

[1] Frisvad JC, Larsen T0, Thrane U, Meijer M, Varga J, Samson RA. Fumonisin and ochratoxin production in industrial Aspergillus niger strains. Plos one. 2011; 6(8): 1-6.

[2] Gheshlaghi R., Scharer, J, Moo-Young M., Douglas P. Metabolic flux analysis for optimizing the specific growth rate of recombinant Aspergillus niger. Bioprocess and Biosystems Engineering. 2007; 30(6): 397-418.

[3] Sheldon RA, Woodley JM. Role of Biocatalysis in Sustainable Chemistry. Chemical Reviews. 2018; 118(2): 801838. 
[4] Maobing T, Chandra RP, Saddler JN. Evaluating the distribution of cellulases and the recycling of free cellulases during the hydrolysis of lignocellulosic substrates. Biotechnology Progress. 2007; 23(2): 398-406.

[5] Harini S, Kumaresan R. Production of cellulase from corn cobs by Aspergillus niger under submerged fermentation. International Journal of ChemTech Research. 2014; 6: 2900-2904.

[6] Voutilainen S, Boer H, Alapuranen M, Janis J, Vehmaanpera J, Koivula A. Improving the thermostability and activity of Melanocarpus albomyces cellobiohydrolase. Applied Microbiology and Biotechnology. 2004; 83: 261 -272 .

[7] Bonet A, Rosell CM, Caballero PA, Gomez M, Perez-Munuera I, Lluch MA. Glucose oxidase effect on dough rheology and bread quality: a study from macroscopic to molecular level. Food Chemistry. 2006; 99: 408-415.

[8] Bilal M, Asgher M, Cheng H, Yan Y, Iqbal HMN. Multi-point enzyme immobilization, surface chemistry, and novel platforms: a paradigm shift in biocatalyst design. Critical Reviews in Biotechnology. 2019; 39: 202-219.

[9] Wilson R, Turner APF. Glucose oxidase: an ideal enzyme. Biosensors and Bioelectronics. 1992; 7: 165-185.

[10] Dakappa S, Adhikari R, Timilsina S, Sajjekhan S. A review on the medicinal plant Psidium guajava linn. (myrtaceae). Journal of Drug Delivery and Therapeutics. 2013; 3(2): 162-168.

[11] Rishika D, Sharma R. An update of pharmacological activity of Psidium guajava in the management of various disorders. International Journal of Pharmaceutical Sciences and Research. 2017; 0-27.

[12] Bezerra CF, Rocha JE, Silva MK, Freitas TS, Sousa AK, Santos ATL, Cruz RP, Ferreira MH, Silva JCP, Machado AJT. Analysis by UPLC-MS-QTOF and antifungal activity of guava (Psidium guajava L.). Food and Chemical Toxicology. 2018; 119: 122-132.

[13] Cakmakci G. Identifying alternative conceptions of chemical kinetics among secondary school and undergraduate students in Turkey. Journal of Chemical Education. 2010; 87: 449-455.

[14] Zhang, YHP and Lynd, LR. Determination of the number-average degree of polymerization of cellodextrins and cellulose with application to enzymatic hydrolysis. Biomacromolecules. 2005; 6: 1510-1515.

[15] Warwick LM, Gray PP, Nippard GJ, Quinlan MR. Evaluation of the DNS method for analysing lignocellulosic hydrolysates. Journal of Chemical Technology and Biotechnology. 1982; 32, 12: 1016-1022.

[16] Hong J, Wang Y, Kumagai H, Tamaki H. Construction of thermotolerant yeast expressing thermostable cellulase genes. Journalof Biotechnology. 2007; 130(2): 114-123.

[17] Zhang YHP, Himmel ME, Mielenz JR. Outlook for cellulase improvement: Screening and selection strategies. Biotechnology Advances. 2006; 24: 452-481. 